DOI: 10.20472/EFC.2018.009.003

\title{
LEANA ESTERHUYSE
}

University of South Africa, South Africa

\section{INVESTOR RELATIONS - ARE NATURAL RESOURCES COMPANIES BETTER? EVIDENCE FROM SOUTH AFRICA.}

\begin{abstract}
:
This paper aims to determine whether natural resources companies have better investor relations practices than companies in other industries, and secondly, whether classification as a natural resources company is a significant predictor of the quality of companies' investor relations practices. The companies under investigation are listed on the Johannesburg Stock Exchange (JSE) of South Africa. Output from natural resources companies is a significant contributor of GDP in South Africa, an emerging and developing economy. In order to attract foreign investors, improve stock pricing and trading liquidity, South African companies need to signal to the capital market at the level that they are used to from companies in developed economies. Communications with the capital market is proxied by investor relations activities on the companies' websites. I find that on average, natural resources companies have significantly better IR practices than companies in other industries. However, in the multivariate model, being a natural resource company is a weak and insignificant predictor of online investor relations quality. Results indicate that larger companies that were listed more recently, had a Big 4 Auditor and were listed on multiple exchanges had significantly better online investor relations practices. From a policy point of view, investor relations officers at natural resources companies can still do more to improve their capital market communication practices to reap the full benefits from increased transparency, especially in the face of political uncertainty and declining or stagnant commodity prices. This study contributes to the theories on signalling and legitimacy by testing its application to natural resource companies in a sub-Saharan country.
\end{abstract}

\section{Keywords:}

Natural resources, South Africa, investor relations, transparency

JEL Classification: D82, 016, Q32 


\section{Introduction}

Companies in the natural resources industry is a major contributor to the economy in South Africa. According to the World Bank (2014a), natural resources contributed almost eight per cent to South Africa's GDP in 2012. Compared to the US, UK, China and Hong Kong ${ }^{1}$, only China came close with approximately six per cent of their GDP contributed by natural resources. The high contribution of natural resources to the GDP of South Africa and China is typical of a developing economy. The importance of natural resources to the economy of South Africa is further evidenced by analyses of the market capitalisation of the Johannesburg Stock Exchange (JSE) in 2012. On 1 June 2012, the total market capitalisation of the JSE Main Board (excluding property income funds) was R6.5 trillion². The 69 natural resource companies' market capitalisation totalled R2 trillion (R29 billion on average), just under a third of the total value. However, South African natural resources companies face political uncertainty, potential sovereign debt rating downgrades and in many cases, declining or stagnant commodity prices. In order to secure scares financial capital, they have to differentiate themselves from the investable universe.

Investors in South African natural resources companies find themselves in a unique capital market. The 2012-2013 World Economic Forum Global Competitiveness Index (WEF 2012: 325) ranked South Africa first out of 144 countries for regulation of its stock exchange, strength of its auditing and reporting standards (mandatory disclosures) and efficacy of corporate boards, thus surpassing developed countries such as the US, UK and European countries. However, in other aspects the JSE behaves more like a stock exchange of an emerging and developing economy, with low stock turnover, absence of retail investors, large long-term blockholders and high transaction costs (JSE, 2014). The share turnover ratio of the JSE was only 55\% in 2012 (World Bank, 2014b). Share turnover over the same period for Hong Kong was $123 \%$, China was $164 \%$, UK was $84 \%$ and the US was $125 \%$ (World Bank, 2014b). In terms of size, the JSE is also small. The World Bank (2014c) reports that in 2012 the US equity market (US $\$ 18,7$ trillion) was 30 times larger than the JSE at US $\$ 612$ billion. The UK (US $\$ 3$ trillion) and China (US $\$ 3,7$ trillion) were 5 and 6 times larger than the JSE and Hong Kong almost twice (US\$1.1 trillion). The hybrid characteristics of the JSE raises the question as to whether natural

\footnotetext{
${ }^{1}$ Comparisons are made to the US and UK (arguably the two major capital markets), China (together with South Africa part of the BRICS countries) and Hong Kong (together with South Africa one of the previous colonies of the UK). See also Debreceny, Gray and Rahman (2002: 382) for the classification of Hong Kong, Singapore and South Africa as 'colonial' countries.

2 Trillion $=10^{12}$.
} 
resources companies will communicate with the capital market to the level of developed countries or developing countries?

Communicating the right information to investors becomes critically important. Investors and analysts do not rely on the annual financial statements alone when they make investment decisions. For example, PricewaterhouseCoopers reports analysts following mining companies consider the following information highly important (>90 per cent) for their analyses: Production volumes, tonnes/ounces sold, average realised prices, cash costs and proven and probable reserves (PWC, 2013: 12). Furthermore, 88 per cent indicated that they agree or strongly agree with the statement that the quality and integrity of reporting affect their perception of the quality and integrity of management (PWC, 2013: 3).

Communicating decision-relevant information to the capital market is a specialised function, usually performed by the investor relations (IR) department of the company (Marston, 2004; Hunter \& Smith, 2009; Bushee \& Miller, 2012; Laskin, 2014). The Investor Relations Society (IRS, 2018) defines IR activities as "the communication of information and insight between a company and the investment community. This process enables a full appreciation of the company's business activities, strategy and prospects and allows the market to make an informed judgement about the fair value and appropriate ownership of a company." Typical IR channels of communication are the printed annual report, investor presentations at road shows, live results conference calls and webcasts, etc. Currently technology allows companies to store these communications on the IR webpages of the corporate website where it is accessible to all. In South Africa, Esterhuyse and Wingard (2016: 228) report that most of the leading JSE companies utilised their websites for IR, but that the quality and extent of these communications on the websites varied widely. They recommend further study into why the IR practices are so divergent (Esterhuyse \& Wingard, 2016: 228). Given the importance of natural resource companies to the economy of South Africa, and the prominence of these companies, the aims of the current study is thus twofold: firstly, to determine if investor relations practices of natural resources companies are better than those of companies in other industries, and secondly, to determine if being a natural resources company is a significant predictor of IR quality in South Africa.

\section{Literature review and hypothesis}

The theoretical foundation of this study lies in information asymmetry and signalling theories. Capital providers lack detailed knowledge of the company's operations, strategies, product markets, and finances, contributing to information asymmetry between 
management of the company and its capital providers. Akerlof (1970) illustrated how information asymmetry leads to 'adverse selection' and the lowering of prices as the lessinformed purchaser offers lower prices to minimise potential future losses. Spence (1973) extended the work of Akerlof by explaining how the better-informed party (management) could incur 'signalling' cost (preparing reports, running a website) by voluntarily communicating more information to the under-informed parties (the current and potential new shareholders and debt providers). The increased signalling has the effect of reducing the cost of information asymmetry (the discount), and thereby increasing the value of the commodity, or security. For this study, IR activities, utilised to communicate additional information to market participants, are deemed a signalling cost.

Empirical studies confirm that companies with higher IR quality (better signalling) indeed benefit from reduced analyst earnings forecast dispersion, bid-ask spread and cost of equity; increased analyst following and investment by institutional investors, and improved share trading volume and valuation multiples (Farragher, Kleiman \& Bazaz, 1994; Brennan \& Tamarowski, 2000; Chang, D’Anna, Watson \& Wee, 2008; Bushee \& Miller, 2012; Agarwal, Taffler, Belloti \& Nash, 2016; Nel, Smit \& Brummer, 2018). The IR webpages on the company's website are especially useful for communicating information in ways that a printed report cannot, e.g. webcasts of investor presentations (Hedlin, 1999; Debreceny et al., 2002; Hunter \& Smith, 2009). The company's online presence also enables two-way communication between the company and its stakeholders via social media (Koehler, 2014).

The focus of this study is on voluntary signals to the capital markets by natural resources companies. Much of the disclosure literature around natural resources companies centres around legitimacy theory. Suchman (1995) proposed that companies endeavour to obtain legitimacy be demonstrating that they comply with society's norms and values. Companies therefore engage in actions and projects that is acceptable to society and then communicate about these efforts. Haniffa and Cooke (2002) postulated that companies in politically sensitive industries, such as mining would be expected to have better disclosure quality in annual reports. Several studies found that natural resources companies use their corporate social responsibility (CSR) and sustainability reporting for legitimacy purposes (Jenkins \& Yakovleva, 2006; Gianfelici, Casadei \& Cembali, 2016; Lee, 2017).

This study's focus is on a different signalling channel used by natural resources companies, namely online IR practices. Several international studies explored whether industry differences exist in online IR quality. Debreceny et al. (2002) found significant differences between industries, with the oil/extractive industry group scoring the second highest for presentation formats and content. Dâmaso and Lourenço (2011) found internet financial reporting quality significantly positively associated with air pollution and 
mining/extractive industries. On the other hand, Bollen, Hassink and Bozic (2006) and Boubaker, Lakhal and Nekhili (2012) found significant associations between online IR quality and the IT industry, whilst Bonson and Escobar (2006) and Dolinšek, Tominc and Skerbinjek (2014) reported that the financial services industry was a significant predictor. Other studies found no industry association with online IR (Desoky, 2009; Uyar, 2012; Fuertes-Callén, Cuellar-Fernández, \& Pelayo-Velázquez, 2014). Internationally, it seems the literature is inconclusive as to whether natural resource companies would be associated with higher online IR.

The mining sector in South Africa is politically sensitive due to very active labour unions and high labour unrest. Dube and Maroun (2017) found that platinum mining companies in South Africa changed their CSR disclosures in response to the fatal protests at the Marikana platinum mine. Looking at IR communications in South Africa, two recent studies investigated the quality of JSE-listed companies' online IR practices. Esterhuyse and Wingard (2016) studied the websites of 205 companies listed on the JSE's main board. They report that six of the top ten online IR scores are from the basic materials sector and these companies were very large in terms of market capitalisation (Esterhuyse \& Wingard, 2016: 227). No further industry analysis is provided. In the second study, Nel, Smit and Brummer (2017: 63) performed a stepwise regression and found the consumer goods, consumer services, financial and technology industries significantly negatively associated with the online IR score. The coefficient of the natural resources industry was insignificant and not reported (eliminated in the stepwise regression). ${ }^{3}$

Similar to international studies, previous studies in South Africa are also undecided on whether natural resources companies are better at online IR than their counter parts in other industries. Given their importance to the South African economy and the size of these natural resources companies, I formulate the following hypotheses:

H1: Online IR quality of natural resources companies are better than online IR quality of companies in other industries.

H2: There is an association between online IR quality in South Africa and belonging to the natural resources industry.

\footnotetext{
3 A limitation of the Nel, Smit and Brummer (2017) study is that the analyses is based on a limited number of companies; 75 listed on the main board and another ten listed on the alternative, development and venture capital board.
} 


\section{Methodology}

This study makes use of secondary data. Quality of IR practices was proxied by an online IR disclosure score. The voluntary online IR disclosure scores (DS) for 205 JSE-listed companies were obtained from Esterhuyse and Wingard (2016). They conducted an extensive content analysis of the websites during July to mid-September 2012 (Esterhuyse \& Wingard, 2016: 219-222).

To test $\mathrm{H} 1$, a comparison of means test was done by way of an independent samples $\mathrm{T}$ test carried out between the online IR disclosure scores of natural resources companies and companies belonging to other industries. $\mathrm{H} 2$ was tested via an ordinary least squares multiple regression run on the following model:

DS $=\alpha+\beta_{1}$ NATRES + CONTROLS $+\varepsilon$

Several studies were conducted since the late 1990s that endeavoured to predict which types of companies used the Internet to communicate with the capital markets and the extent, or quality of these disclosures. These studies were initially conducted on US-listed companies (Ashbaugh, Johnstone \& Warfield, 1999; Ettredge, Richardson \& Scholz, 2002), UK-listed companies (Craven \& Marston, 1999; Abdelsalam, Bryant \& Street, 2007) and European companies (Pirchegger \& Wagenhofer, 1999; Geerings, Bollen \& Hassink, 2003; Boubaker, Lakhal \& Nekhili, 2012; Satta, Parola, Profumo \& Penco, 2015). During the last few years, studies were published from emerging and developing economies (Desoky, 2009; Uyar, 2012; Nurunnabi \& Hossain, 2012; Dolinsek, Tominc \& Skerbinjek, 2014; Fuertes-Callen, Cuellar-Fernandez \& Pelayo-Velaquez, 2014). The most common factors associated with the quality of online IR were company size, ownership concentration (or free float), number of years listed, whether additional shares were issued recently, profitability, debt ratio, whether the company is also listed on another exchange and if the audit firm is part of the Big 4. These were included as control variables. The full model is as follows:

\footnotetext{
DS $=\alpha+\beta_{1}$ NATRES $+\beta_{2}$ LNCAP $+\beta_{3}$ OC $+\beta_{4}$ LNAGE $+\beta_{5}$ IssuedNew $+\beta_{6}$ ROaA_Win + $\beta_{7}$ LNDE $+\beta_{8}$ Big4Auditor $+\beta_{9}$ Dual_list $+\varepsilon$ 
Unless otherwise stated, the data for the independent variables were obtained from the IRESS database (containing data about JSE listed companies) for all 205 companies and exported to Excel. From Excel the data was uploaded to SPSS and various statistical analyses were run on the data. Please refer to Table 1 for the measurements of the independent variables.

\section{Table 1: Independent variables measurements}

\begin{tabular}{|l|l|}
\hline Variable & Measurement \\
\hline NATRES & $\begin{array}{l}\text { Dummy variable coded '1' if the company's industry was classified as a Natural } \\
\text { Resources company and '0' otherwise. } \\
\text { The classification is done based on the Industry Classification Benchmark (ICB). } \\
\text { Companies classified into Super Sector 0500 'Oil \& Gas' and 1700 'Basic Resources' } \\
\text { were coded '1'. }\end{array}$ \\
\hline MCAPbillions & $\begin{array}{l}\text { Market capitilisation from FTSE/JSE Index composition during June 2012, in R'109. } \\
\text { (JSE, 2012) }\end{array}$ \\
\hline $\begin{array}{l}\text { LNCAP } \\
\text { OC } \\
\text { concentration): }\end{array}$ & $\begin{array}{l}\text { A natural logarithm transformation was applied to MCAPbillions to achieve normality of } \\
\text { the distribution. } \\
\text { I utilise the board independence indicator from the Orbis database of Bureau van Dijk } \\
\text { period recorded before 1 July 2012 as a measure of ownership concentration. The }\end{array}$ \\
\hline $\begin{array}{l}\text { classifications (Bureau van Dijk, 2016) are: } \\
>25 \%\end{array}$ & $\begin{array}{l}\text { A = Attached to any company with known recorded shareholders none of which have } \\
\text { more than 25\% direct or total ownership. }\end{array}$ \\
\hline $\begin{array}{l}\text { This was coded 'None >25\%', and is a rough indicator of a company with more } \\
\text { dispersed shareholding. }\end{array}$ \\
$\begin{array}{l}\text { B = Attached to any company with known recorded shareholders none of which with an } \\
\text { ownership percentage (direct, total or calculated total) over 50\%, but having one or } \\
\text { more shareholders with an ownership percentage above 25\%. } \\
\text { This was coded 'One or more }>25 \% \text { ', and is indicative of a company with substantial } \\
\text { blockholdings. }\end{array}$ \\
\hline
\end{tabular}




\begin{tabular}{|c|c|}
\hline Variable & Measurement \\
\hline - Controlled & $\begin{array}{l}\text { C = Attached to any company with one recorded shareholder with a total or a } \\
\text { calculated total ownership over } 50 \% \text {. } \\
D=\text { This is allocated to any company with one recorded shareholder with a direct } \\
\text { ownership of over } 50 \% \text {. Branches and foreign companies are also being attributed an } \\
\text { indicator 'D'. As there were very few C's, I grouped C and D together as these } \\
\text { companies are 'Controlled'. } \\
\text { In the regression analysis, 'Controlled' became the reference category. }\end{array}$ \\
\hline Age & $\begin{array}{l}\text { Date that company started trading on the JSE relative to } 30 \text { June 2012, in full years } \\
\text { (months and days dropped). System missing information on listing date was hand } \\
\text { collected from the company's website. }\end{array}$ \\
\hline LNAGE & $\begin{array}{l}\text { A natural logarithm transformation was applied to Age to achieve normality of the } \\
\text { distribution. }\end{array}$ \\
\hline IssuedNew & $\begin{array}{l}\text { Dummy variable coded ' } 1 \text { ' if company had new issue of shares during the preceding } 24 \\
\text { months before } 1 \text { July } 2012 \text {. } \\
\text { First, I calculated the change in issued number of shares from one year to the next. } \\
\text { Then I identified those companies that had a change greater than five per cent. } \\
\text { Changes in issued shares smaller than five per cent were 'allowed' to accommodate } \\
\text { changes due to employee shareowner schemes (Jankensgård, 2015: } 869 \text { ). Changes } \\
\text { that were flagged were then manually confirmed with company documents as relating } \\
\text { to additional issue of shares to the public or existing shareholders. }\end{array}$ \\
\hline $\mathrm{ROaA}$ & $\begin{array}{l}\text { Return on average total assets ratio for the financial year ending at least three months } \\
\text { before } 1 \text { July } 2012 \text { (the start of the fieldwork). The period of three months is for } \\
\text { preparing the audited financials. }\end{array}$ \\
\hline ROaA_win & $\begin{array}{l}\text { Ten outliers distorted the distribution. The variable was sorted from small to large. The } \\
\text { first five cases from the top and the bottom five cases were winsorized to the value of } \\
\text { the sixth case respectively. This is acceptable as it is within a five per cent range of the } \\
\text { sample size. }\end{array}$ \\
\hline $\mathrm{DE}$ & $\begin{array}{l}\text { Debt to equity ratio for the financial year ending at least three months before } 1 \text { July } \\
2012 \text { (the start of the fieldwork). }\end{array}$ \\
\hline LNDE & $\begin{array}{l}\text { A natural logarithm transformation was applied to DE to achieve normality of the } \\
\text { distribution. }\end{array}$ \\
\hline Big4Auditor & $\begin{array}{l}\text { Dummy variable coded ' } 1 \text { ' if auditors are Deloitte, Ernst \& Young, } \\
\text { PricewaterhouseCoopers or KPMG, otherwise '0'. }\end{array}$ \\
\hline
\end{tabular}




\begin{tabular}{|l|l|}
\hline Variable & Measurement \\
\hline Dual_List & $\begin{array}{l}\text { Dummy variable coded '1' if the company's shares were also listed on another stock } \\
\text { exchange, otherwise '0'. }\end{array}$ \\
\hline
\end{tabular}

Source: Own

\section{Results and discussion}

The descriptive statistics for the untransformed continuous data is presented in Table 2 Panel A and the categorical data in Panel B. The average online IR disclosure score for the 205 JSE-listed companies is 39.78 per cent with a standard deviation of 13.55 per cent, indicative of a large variation in online IR practices (Esterhuyse \& Wingard, 2016: 222). The average market capitalisation of the sample companies was R31.2 billion $\left(R^{\prime} 10^{9}\right)$, bringing their total market capitilisation to $R 6.4$ trillion $\left(R^{\prime} 10^{12}\right)$. The sample therefore constitutes about 98 per cent of the market capitilisation of JSE-listed companies in June 2012. On average, the companies in the sample were listed for 26 years, with a return on average assets of 8.65 per cent and a debt/equity ratio of 2.78 times.

The sample consisted of 39 (19 per cent) companies classified as belonging to the natural resources industries. Over half of the companies had a shareholder profile indicating that no individual shareholder held more than 25 per cent of the shares. A fifth of companies were controlled by one major shareholder. Fifty-nine companies had an additional equity listing (seasoned equity offer) during the preceding 24 months. The audits of the samples companies are dominated by the Big 4 firms, representing 82.4 per cent of the auditors. Almost a quarter of the companies had an additional listing on another stock exchange apart from the JSE.

To test the first hypothesis, I ran an independent samples T-test on the online IR disclosure scores of natural resources companies and those that are in different industry classifications. Companies in the natural resources sector had a higher mean online IR disclosure score of 44.71 per cent compared to the mean of 38.62 per cent for the nonnatural resources companies. The assumption of homogenous variances within each group was accepted (Levene $\mathrm{F}(203)=1.284, \mathrm{p}>0.01)$ and the test $(\mathrm{t}(203)=6.562$, $p<0.05)$ indicated that the differences between the disclosure behaviour of companies classified as natural resources companies and others were statistically significant. I could find not reason to reject $\mathrm{H} 1$. This finding is consistent with the legitimacy theory that natural resources companies disclose more. The fact that the online IR score of the natural resources companies were higher is also indicative of their attempt to improve 
their signals to the capital market participants and to comply with international guidelines on online IR practices.

Table 2: Descriptive statistics

\begin{tabular}{|l|r|r|r|r|}
\hline Panel A & Mean & Minimum & Maximum & Std. Deviation \\
\hline DS & .3978009 & .04098 & .66393 & .13548196 \\
\hline MCAPbillions & 31.16256 & .031 & 812.411 & 86.705455 \\
\hline Age & 26.11 & 1 & 117 & 21.892 \\
\hline ROaA_win & 8.6459 & -19.38 & 34.64 & 10.87553 \\
\hline DE & 2.4726 & .01 & 164.99 & 11.81064 \\
\hline
\end{tabular}

\begin{tabular}{|c|c|c|c|}
\hline \multirow{2}{*}{\multicolumn{2}{|c|}{ Categorical variables }} & \multirow{3}{*}{$\begin{array}{r}\text { Frequency } \\
166\end{array}$} & \multirow{3}{*}{$\begin{array}{r}\text { Percent } \\
81.0\end{array}$} \\
\hline & & & \\
\hline \multirow[t]{3}{*}{ Natural Resources Industry } & Other industries & & \\
\hline & Natural Resources & 39 & 19.0 \\
\hline & Total & 205 & 100.0 \\
\hline \multirow[t]{4}{*}{ Ownership Concentration } & Controlled & 42 & 20.5 \\
\hline & One or more $>25 \%$ & 43 & 21.0 \\
\hline & None $>25 \%$ & 120 & 58.5 \\
\hline & Total & 205 & 100.0 \\
\hline \multirow[t]{3}{*}{ Issued New Shares } & No additional equity listed & 146 & 71.2 \\
\hline & Additional equity listed & 59 & 28.8 \\
\hline & Total & 205 & 100.0 \\
\hline
\end{tabular}




\begin{tabular}{|l|l|r|r|}
\hline Big 4 Auditors & Non-Big 4 Auditor & 36 & 17.6 \\
\cline { 2 - 4 } & Big 4 Auditor & 169 & 82.4 \\
\cline { 2 - 4 } & Total & 205 & 100.0 \\
\hline Dual Listed & Only JSE & 157 & 76.6 \\
\cline { 2 - 4 } & Dual listed & 48 & 23.4 \\
\cline { 2 - 4 } & Total & 205 & 100.0 \\
\cline { 2 - 4 } & & & \\
\hline
\end{tabular}

Source: Own from SPSS

The results of the bivariate correlation tests between all variables are presented in Table 3. Pearson correlations are presented in the bottom triangle and Spearman correlations in the top triangle. Being classified as a natural resources company is moderately positively associated with the online IR disclosure score $(r=0.177)$ and significant at the 0.05 level. This provides provisional support for the hypothesis that natural resources companies should be better at capital market communications, as measured in the online IR disclosure score. Market capitilisation has the strongest correlation with the online IR disclosure score $(r=.665)$ and is highly significant at the 0.01 level. This finding is consistent with the theory that larger companies have more slack resources to spend on their online presence and other disclosure features. Size had the largest correlation of all the variables with the online IR disclosure score. Having a Big 4 auditor and being duallisted were moderately positively correlated with the online IR disclosure score and significant at a 0.01 level. This is consistent with findings from prior studies. Profitability was only weakly positively significant at a 0.05 level. Ownership concentration, number of years listed, debt/equity ratio and issuance of new shares were not significantly associated with online IR quality.

There were also a few significant correlations between the independent variables, which raises the issue of collinearity. The highest correlation $(r=0.404)$, was between Big 4 Auditors and market capitilisation $(p<0.01)$, which is still below 0.9 , the point at which collinearity becomes a problem (Field, 2009: 233). This is consistent with the practice that large companies are audited by Big4 auditors. The Variance Inflation Factors will be discussed with the results of the regression analysis, but collinearity does not seem to pose a problem at this stage. 


\section{Table 3: Correlation matrix}

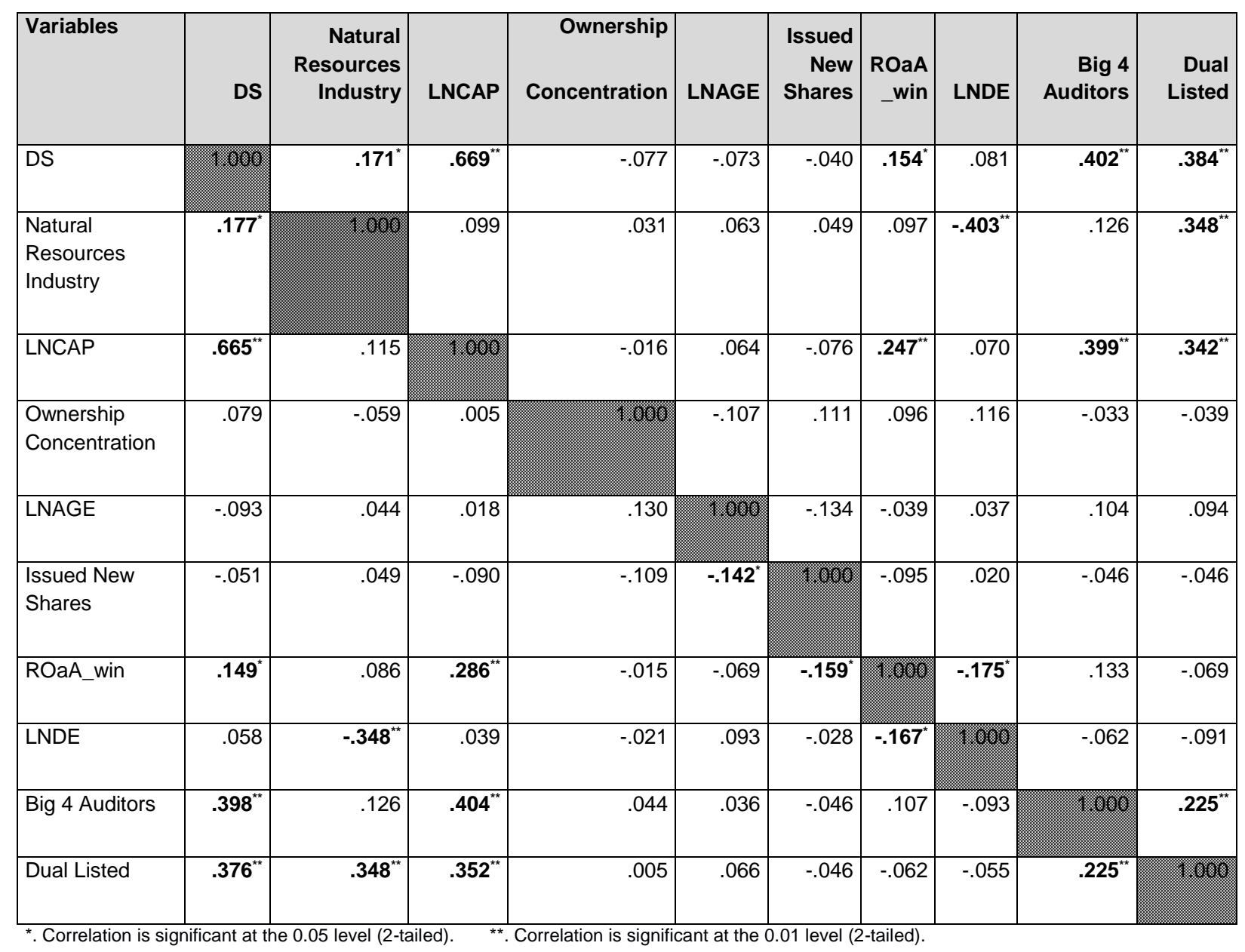

Source: Own from SPSS

To test $\mathrm{H} 2$, an ordinary least squares multiple regression was conducted. As described in the methodology section, certain variables were transformed to improve normality. The results of the ordinary least squares regression is presented in Table 4. The $F$ statistic indicate that the model is significant at the $p<0.001$ level. The overall model has average strength in predicting online IR quality in South Africa (Adjusted $R^{2}=.488$ ). This Adjusted $R^{2}$ compares favourably with that of Abdelsalam et al. (2007: 20) of 110 London companies (Adjusted $R^{2}=.358$ ), Boubaker et al. (2012: 144) of 529 companies in France (Adjusted $R^{2}=.513$ ), Nurunnabi and Hossain (2012: 33) of 83 companies in Bangladesh (Adjusted $R^{2}=.368$ ) and Nel et al. (2017: 63) of 85 companies in South Africa (Adjusted $\left.R^{2}=.688\right)$. 
Table 4: Results of OLS regression

\begin{tabular}{|c|c|c|c|c|c|c|}
\hline \multirow{2}{*}{$\begin{array}{l}\text { Model } 1 \\
\text { Dependent: Online } \\
\text { IR disclosure score }\end{array}$} & \multicolumn{2}{|c|}{$\begin{array}{l}\text { Unstandardized } \\
\text { Coefficients }\end{array}$} & \multirow{2}{*}{$\begin{array}{c}\text { Standardized } \\
\text { Coefficients } \\
\text { Beta }\end{array}$} & \multirow[t]{2}{*}{$\mathbf{t}$} & \multirow[t]{2}{*}{ Sig } & \multirow[t]{2}{*}{ VIF } \\
\hline & B & Std. Error & & & & \\
\hline (Constant) & -.374 & .081 & & -4.601 & .000 & \\
\hline $\begin{array}{l}\text { Natural Resources } \\
\text { Industry }\end{array}$ & .033 & .020 & .097 & 1.677 & .095 & 1.323 \\
\hline LNCAP & .034 & .004 & .554 & 9.024 & $.000^{\star \star}$ & 1.502 \\
\hline One or more $>25 \%$ & .008 & .021 & .024 & .378 & .706 & 1.655 \\
\hline None $>25 \%$ & .025 & .018 & .093 & 1.440 & .151 & 1.657 \\
\hline LNAGE & -.019 & .008 & -.127 & -2.462 & $.015^{\star}$ & 1.061 \\
\hline $\begin{array}{l}\text { Issued New Shares } \\
\text { prev } 24 \text { months }\end{array}$ & -.007 & .016 & -.022 & -.419 & .675 & 1.080 \\
\hline ROaA_win & .000 & .001 & -.030 & -.538 & .591 & 1.257 \\
\hline LNDE & .010 & .006 & .093 & 1.687 & .093 & 1.215 \\
\hline Big 4 Auditors & .054 & .020 & .152 & 2.733 & $.007^{\star *}$ & 1.230 \\
\hline Dual Listed & .041 & .019 & .127 & 2.183 & $.030^{\star}$ & 1.357 \\
\hline \multicolumn{6}{|c|}{ Model summary } & \\
\hline & \multicolumn{3}{|c|}{$\mathrm{R}^{2}$} & & .513 & \\
\hline & \multicolumn{3}{|c|}{ Adjusted $\mathrm{R}^{2}$} & & .488 & \\
\hline & \multicolumn{3}{|c|}{ F value } & \multicolumn{2}{|r|}{20.469} & \\
\hline & \multicolumn{3}{|c|}{$p$ value } & \multicolumn{2}{|r|}{$.000^{\star *}$} & \\
\hline
\end{tabular}


Model 1: DS $=\alpha+\beta_{1}$ NATRES $+\beta_{2}$ LNCAP $+\beta_{3}$ OC $+\beta_{4}$ LNAGE $+\beta_{5}$ IssuedNew $+\beta_{6}$ ROaA_Win $+\beta_{7}$ LNDE + $\beta_{8}$ Big4Auditor $+\beta_{9}$ Dual_list $+\varepsilon$

Source: Own from SPSS

Natural resources was found to be positively associated with online IR quality, which is consistent with the signalling and legitimacy theories, but was only weakly significant at the $p<0.1$ level. If a cut-off for significance were set at conventional levels of $p<0.05$, this variable of interest would not be deemed a significant predictor in a multivariate model. $\mathrm{H} 2$ is therefore rejected that for JSE-listed companies there is an association between natural resource classification and the quality of capital market communications as measured by an online IR disclosure score.

As is found in most disclosure studies, company size (market capitilisation) is found to be positively associated with the online IR score and it was a highly significant variable $(p<$ $0.000)$. Having a Big 4 Auditor was also highly significant $(p<0.01)$ and positively associated with the online IR disclosure scores. This is consistent with prior studies finding that annual and sustainability reporting also being positively associated with having a Big 4 Auditor. Number of years listed has a negative co-efficient, meaning that 'younger' companies have better IR practices. This can be explained by their more recent interaction with the capital market when they had their initial public offering. Age was a significant predictor $(p<0.05)$. In line with prior studies, companies with listings in other capital markets had better online IR disclosure scores. These companies are subjected to international investors and regulations that requires higher disclosures. Dual listing status was significant at the 0.05 level. Ownership concentration, issuing new shares, return on average assets and debt/equity ratio were not significant in the multivariate model for predicting online IR quality.

The Variance Inflation Factor (VIF) for each independent variable is below two. Furthermore, the average VIF is 1.334 which is not substantially greater than one (Field, 2009: 242). I also investigate the Variance Proportions for the small Eigenvalues. I find that not one of the Eigenvalues has two or more large Variance Proportions loaded against it. I conclude that multicollinearity is not a problem for the predictor variables in the regression model.

\section{Conclusions}

Natural resources companies are important contributors to the South African economy. These are also some of the largest companies listed on the JSE. As such, these companies are constantly in the public eye. The aims of the study was to establish 
whether natural resources companies listed on the JSE had IR practices that were better than companies in other industries, and secondly to determine in a multivariate model, whether classification as a natural resources company is a significant predictor of $I R$ quality. In a comparison of group means, I find that companies in the natural resources sector had a higher mean online IR disclosure score of 44.71 per cent compared to the mean of 38.62 per cent for the non-natural resources companies. Having better disclosure practices is consistent with legitimacy theory, especially in the natural resources industry. However, IR officers in natural resources companies can still improve on their IR practices, considering that the average online IR score of 44.71 per cent is still below 50 per cent, based on international standards.

Membership of the natural resources industry was also positively correlated $(r=0.177 ; p$ $<0.05)$ with the online IR quality. However, when put into a multivariate model for predicting online IR disclosure scores, classification as a natural resources company was no longer a significant predictor. The hypothesis was rejected, although the coefficient was still positive and consistent with the theories of signalling and legitimacy. The control variables indicate that larger companies that were listed more recently, had a Big 4 Auditor and were listed on multiple exchanges had significantly better online IR practices.

This study contributes to the theories on signalling and legitimacy by extending it to an emerging and developing economy in sub-Sahara Africa with low share turnover and high natural resource dependency. The signalling channel was the companies' IR webpages, and this signalling channel has not been studied in much detail before in South Africa. Building and operating a state of the art investor relations website requires investment in personnel and IT resources. The results of the paper may therefore interest preparers and investor relations officers by informing their disclosure policies and making cost/benefit decisions. The limitations of the study is mainly that it was based on a selection of only 205 companies, even though the companies in the sample comprised $98 \%$ of the capitilisation of the JSE on date of selection. In order to determine why online IR practices of natural resources companies are better than those in other industries in South Africa, it is suggested that future studies apply the multivariate online IR model to the natural resources industry on its own. The study could also be repeated to determine if there were temporal differences in online IR practices, and drivers for such changes.

\section{References}

Abdelsalam, O.H., Bryant, S.M. \& Street, D.L. 2007. An Examination of the Comprehensiveness of Corporate Internet Reporting Provided by London-Listed Companies. Journal of International Accounting Research, 6(2), 1-33. 
Agarwal, V., Taffler, R.J., Bellotti, X. \& Nash, E.A. 2016. Investor relations, information asymmetry and market value. Accounting and Business Research, 46(1):31-50.

Akerlof, G. 1970. The Market for Lemons: Quality Uncertainty and the Market Mechanism. Quarterly Journal of Economics, 84, 485-500.

Ashbaugh, H., Johnstone, K. M. \& Warfield, T. D. 1999. Corporate Reporting on the Internet, Accounting Horizons, 13(3), 241-258.

Bollen, L., Hassink, H. \& Bozic, G. 2006. Measuring and explaining the quality of Internet investor relations activities: a multinational empirical analysis. International Journal of Accounting Information Systems, 7, 273-298.

Bonson, E. \& Escobar, T. 2006. Digital reporting in Eastern Europe: An empirical study. International Journal of Accounting Information Systems, 7, 299-318.

Boubaker, S., Lakhal, F. \& Nekhili, M. 2012. The determinants of web-based corporate reporting in France. Managerial Auditing Journal, 27(2), 126-155.

Brennan, M.J. \& Tamarowski, C. 2000. Investor relations, liquidity, and stock prices. Journal of Applied Corporate Finance, 12(4), 26-37.

Bureau van Dijk. 2016. BvD Independence Indicator. Bureau van Dijk. [Online] Available from https://help.bvdinfo.com/mergedProjects/WHDOTNETOWNERSHIP EN/Ownership/BVDINDIN NE W.htm [Accessed on 15 March 2016].

Bushee, B.J. \& Miller, G.S. 2012. Investor Relations, Firm visibility, and Investor Following. The Accounting Review, 87(3), 867-897.

Chang, M., D’Anna, G., Watson, I. \& Wee, M. 2008. Does disclosure Quality via Investor Relations Affect Information Asymmetry? Australian Journal of Management, 33(2), 375-390.

Craven, B. M. \& Marston C. L. 1999. Financial reporting on the Internet by leading UK companies. The European Accounting Review, 8(2), 321-333.

Dâmaso, G., \& Lourenço, I. 2011. Internet Financial Reporting: Environmental impact companies and other determinants. $8^{\text {th }}$ International Conference on Enterprise Systems, Accounting and Logistics, 11-12 July 2011, Thassos Island, Greece.

Debreceny, R., Gray, G., \& Rahman, A. 2002. The determinants of Internet financial reporting. Journal of Accounting and Public Policy, 21, 371-394.

Desoky, A.M. 2009. Company characteristics as determinants of Internet Financial Reporting in emerging markets: The case of Egypt. Accounting in Emerging Economies, 9, 31-71.

Dolinšek, T., Tominc, P., \& Skerbinjek, A. 2014. The determinants of internet financial reporting in Slovenia. Online Information Review, 38(7), 842-860. 
Dube, S. \& Maroun, W. 2017. Corporate social responsibility reporting by South African mining companies: Evidence of legitimacy theory. South African Journal of Business Management, 48(1):23-34.

Esterhuyse,L. \& Wingard, C.. 2016. An exploration of the online investor relations (IR) practices of companies listed on the Johannesburg Stock exchange (JSE), South African Journal of Economic and Management Sciences, 19(2), 215-231.

Ettredge, M., Richardson, V. J. \& Scholz, S. 2002. Dissemination of information for investors at corporate Websites. Journal of Accounting and Public Policy, 21(4-5), 357-369.

Farragher, E.J., Kleiman, R. \& Bazaz, M.S. 1994. Do investor relations mak.e a difference? The Quarterly Review of Economics and Finance, 34(4), 403-412.

Field, A. 2009. Discovering statistics using SPSS. $3^{\text {rd }}$ ed. London: SAGE Publications Ltd.

Fuertes-Callén, Y., Cuellar-Fernández, B., \& Pelayo-Velázquez, M. 2014. Determinants of online corporate reporting in three Latin American markets, Online Information Review, 38(6), 806-831.

Geerings, J., Bollen, L.H.H. \& Hassink, H.F.D. 2003. Investor relations on the Internet: a survey of the Euronext zone, The European Accounting Review, 12(3), 567-579.

Gianfelici, C., Casadei, A. \& Cembali, F. 2016. The Relevance of Nationality and Industry for Stakeholder Salience: An Investigation through Integrated Reports. Journal of Business Ethics. In press.

Haniffa, R. \& Cooke, T. 2002. Culture, corporate governance and disclosure in Malaysian corporations. ABACUS, 38(3), 317-349.

Hedlin, P. 1999. The Internet as a vehicle for investor relations: the Swedish case, The European Accounting Review, 8(2), 373-381.

Hunter, S.A \& Smith, M. 2009. Impact of Internet Financial Reporting on Emerging Markets. Journal of International Business Research, 8(2), 21-41.

Investor Relations Society. 2018. About the IR Society, IR Society, London. [Online] http://irsociety.org.uk/about accessed 26 March 2018.

IRS - see Investor Relations Society.

Jankensgård, H. 2015. The relationship between voluntary disclosure, external financing and financial status. Journal of Business Finance \& Accounting, 42(7-8):860-884.

Jenkins, H. \& Yakovleva, N. 2006. Corporate social responsibility in the mining industry: Exploring trends in social and environmental disclosure. Journal of Cleaner Production, 14(3-4):271-284.

Johannesburg Stock Exchange. 2012. FTSE/JSE Index Series Quarterly Review - June 2012. JSE.

[Online] Available from

https://www.jse.co.za/content/JSEIndexReviewltems/20120606\%20\%20June\%20Quarterly\%20Index \%20Review\%20Paper\%20Market.xls [Accessed on 2 February 2016]. 
Johannesburg Stock Exchange. 2014. Increasing Market Liquidity - identifying barriers to liquidity, enabling cross-membership, pooling liquidity across markets. 2014 Conference on Building African Financial Markets, 12 September 2014, Johannesburg, South Africa. Johannesburg Stock Exchange (JSE). [Online] Available from https://www.jse.co.za/content/JSEPresentationltems/BAFM\%202014 Increasing\%20market\%20liqui dity.pdf [Accessed on 4 November 2016].

JSE - see Johannesburg Stock Exchange.

Koehler, K. 2014. Dialogue and Relationship Building in Online Financial Communications. International Journal of Strategic Communication, 8(3):177-195.

Laskin, A.V. 2014. Investor Relations as a Public Relations Function: A State of the Profession in the United States. Journal of Public Relations Research, 26(3):200-214.

Lee, K. 2017. Does Size Matter? Evaluating Corporate Environmental Disclosure in the Australian Mining and Metal Industry: A Combined Approach of Quantity and Quality Measurement. Business Strategy and the Environment, 26(2):209-223.

Marston, C. 2004. A Survey of European Investor Relations. Edinburgh: Institute of Chartered Accountants of Scotland.

Nel, G.F., Smit, E. vdM. \& Brummer, L.M. 2017. Determinants of the quality of internet investor relations A study of companies listed on the JSE. South African Journal of Business Management, 48(1):5565.

Nel, G.F., Smit, E.vdM. \& Brümmer, L.M. 2018. The Impact of Internet Investor Relations on the Cost of Capital: Evidence from Companies Listed on the Johannesburg Stock Exchange. Australian Accounting Review, In press.

Nurunnabi, M. \& Hossain, M.A. 2012. The voluntary disclosure of internet financial reporting (IFR) in an emerging economy: a case of digital Bangladesh. Journal of Asia Buiness Studies, 6(1), 17-42.

Pirchegger, B. \& Wagenhofer, A. 1999. Financial information on the Internet: a survey of the homepages of Austrian companies, The European Accounting Review, 8(2), 383-395.

PWC. 2013. Extracting Value. What do investment professionals need from mining company reporting? PricewaterhouseCoopers. [Online] https://www.pwc.com/gx/en/mining/publications/assets/pwcextracting-value-what-do-investment-professionals-need-from-mining-company-reporting.pdf [Accessed 5 November 2016].

Satta, G., Parola, F., Profumo, G., \& Penco, L. 2015. Corporate governance and the quality of voluntary disclosure: Evidence from medium-sized listed firms. International Journal of Disclosure and Governance, 12(2), 144-166.

Spence, M. 1973. Job Market Signalling. Quarterly Journal of Economics, 87, 355-374. 
Suchman, M.C. 1995. Managing legitimacy: Strategic and institutional approaches. Academy of management review, 20(3):571-610.

Uyar, A. 2012. Determinants of corporate reporting on the internet - An analysis of companies listed on the Istanbul Stock Exchange (ISE). Managerial Auditing Journal, 27(1), 87-104.

WEF. 2012. The Global Competitiveness Report. Geneva: World Economic Forum.

World Bank. 2014a. Total natural resources rents (\% of GDP). World Development Indicators, World Bank [Accessed using Google Public Data Explorer on 25 October 2014].

World Bank. 2014b. Stocks traded, turnover ratio (\%). World Development Indicators, World Bank [Accessed using Google Public Data Explorer on 25 October 2014].

World Bank. 2014c. Market capitilisation of listed companies (Current US\$). World Development Indicators, World Bank [Accessed using Google Public Data Explorer on 25 October 2014]. 